\title{
VÁLLALATI KOCKÁZATI FAKTOROK AZ EU ETS-RENDSZERBEN
}

Az Európai Unió az Egyesült Államok távolmaradásával vezetố szerepet kapott a kiotói jegyzốkönyv kialakításában és elfogadtatásában. A tagállamok vállalásaik költséghatékony teljesítése érdekében létrehozták az európai emissziókereskedelmirendszert (EU ETS), amely a világ legnagyobb szennyezésijog-piaca lett. A rendszer életbe lépésével a kötelezett vállalatoknak új kockázati elemmel kellett szembenézniük: az éves kibocsátásuknak megfelelố mennyiségú emissziós kvótát kell évente visszajuttatni a hatóságokhoz. Az emissziókereskedelmi rendszerben a vállalat év közben két kockázati faktorral szembesül: nem tudja elốre megmondani, mennyi szén-dioxidot fog kibocsátani, és így azt sem, mennyi kvótával kell megfeleléskor rendelkeznie. Emellett az is bizonytalan, hogy a szükséges kvótamennyiséget milyen áron lesz képes beszerezni, vagy a feleslegeseket értékesíteni. A vállalat év közbeni állapotához képest veszít, ha év végén kvótafelesleggel rendelkezik, és az árak alacsonyabbak lesznek. Szintén veszteséget szenved el pozícióján kvótahiány esetén növekvố árak mellett. A cikkben a szerzố egy eljárást ismertet, amelynek segítségével termék- és erôforrásárakra támaszkodva elốre lehet jelezni a vállalati emissziót, és bemutatja, milyen kvótamennyiséget érdemes tartani a várható értékéhez képest számított kockáztatott érték minimalizálása érdekében.

\section{Kulcsszavak: EU ETS, kibocsátás szimulációja, kockáztatott érték}

A XX. század vége felé közeledve egyre biztosabbá vált, hogy az iparosodás miatt bekövetkezô jelentôs mértékú szén-dioxid-kibocsátás hosszú távú globális klímaváltozást okoz. A kibocsátott üvegházhatású gázok nem ismernek államhatárokat, a légkörben elkeveredve az egész Föld éghajlatára hatással vannak. Az ipari emisszió kihat az egész emberiség jólétére (általában csökkenti azt), a hatás nem szándékolt, az érintett felek nincsenek kompenzálva az elszenvedett kárért. A kritériumok alapján (Kerekes, 2007, 118. o.) a jelenség egy tipikus példa a piaci kudarcra, az externáliára.

\section{Út az európai emissziókereskedelmi rendszerig}

A globális szennyezés és hatás miatt a problémát csak nemzetközi együttmúködés keretében lehet eredményesen kezelni. A probléma súlyosságának felismerését követően 1997-ben megszületett a kiotói egyezmény, amelyben a fejlett és átmeneti gazdaságú országok vállalták, hogy bázisidőszakukhoz (ez általában az 1990es szint) képest meghatározott mértékben korlátozzák kibocsátásaikat.
A globális egyezmény megszületése - Kiotói Protokoll

A szerződés hatályba lépésének feltétele az volt, hogy az üvegházhatású gázok összes kibocsátásának legalább 55 százalékáért felelôs államok ratifikálják azt. Az Amerikai Egyesült Államok távolmaradásával kérdésessé vált a szerződés életképessége, ez a helyzet csak 2004-ben oldódott meg, amikor egy másik jelentốs szennyezô - Oroszország - is aláírta a szerzódést. Az életbe lépéssel kapcsolatos bizonytalanság és a hétéves csúszás jól szemlélteti az ellentétek erejét az egyes országok rövid távú gazdasági érdekei és az emberiség hosszú távú globális érdekei között.

\section{Az Európai Unió szerepvállalása}

A közösségi szintú környezetvédelmi együttmúködés elsố jelentős lépcsôje az 1986-os Single Europan Act, amelyben hangsúlyt kapott a környezeti kihívások költséghatékony, közösségi szinten történő kezelése. Az üvegházhatású gázok kibocsátásának korlátozása és az externália internalizálása érdekében 1992-ben az Európai Bizottság közösségi szintú szén-dioxid-adó bevezetését javasolta. A tervezet nem valósult meg, mi- 
vel egyrészt az európai szintú adóban néhány tagállam a fiskális autonómiájának csökkentését látta, másrész az ellenérdekelt energialobbyi jelentôs érdekérvényesítô képességgel rendelkezett (Convery - De Perthuis Ellerman, 2008)

A kiotói jegyzókönyvhöz vezető tárgyalásokban az unió meghatározó szerepet vállalt, kezdeti álláspontja egységes 15 százalékos csökkentési szint bevezetése és az emissziókereskedelem mint eszköz elvetése volt. vezetố szerepet a nemzetközi klímavédelemben.

A jegyzókönyvben az EU közösségi szinten 8 százalékos csökkentést vállalt, az EU-buborékon beliil az egyes országok teljesítésének meghatározásába szabad kezet kapott. Az egyes tagországok kibocsátási céljait (amelyeknek eredményeképpen az unió célkitûzés megvalósul) a tehermegosztási egyezmény (Burden Sharing Agreement) definiálta. Ebben a fejlettebb tagállamok nagyobb arányú csökkentést vállaltak, míg a kevésbé fejlett tagállamok kibocsátásai növekedhettek (European Environment Agency 2002). A emissziós célok költséghatékony teljesítése érdekében hozták létre az európai kvótakereskedelmi rendszer (Emission Trading Scheme - EU ETS), melynek alapjait a 2003/87/EC direktíva rakta le.

\section{Magyarországi lépések} Magyarország) a jegyzókönyv szempontjából speciális helyzetben voltak, ugyanis a gazdasági szerkezetváltás miatt korábbi jelentôs ipari termelésük, energiaigényü és ezzel üvegházhatásúgáz-kibocsátásuk a 1980-as évek végén jelentősen visszaesett. Ezek az államok lehetőséget kaptak arra, hogy viszonyítási alapjuk (amelyhe képest kell megvalósítani a csökkentést) nem az 1990es, hanem a korábbi évek legyenek. Ez Magyarország esetében azt jelentette, hogy az általunk vállalt 6 százapest kell megvalósítanunk, amit gyakorlatilag minden jelentősebb erőfeszítés nélkül el tudunk érni.

\section{Az európai emissziókereskedelmi rendszer} (EU ETS) bemutatása

Az emissziós piac elméleti hátterét Coase tétele (Coase, 1960) adja, mely szerint az externáliák kezelésének sikeres módja a tulajdonjogok definiálása és kiosztása, mely után tárgyalásos úton valósul meg a társadalmi szintú optimum (feltéve, hogy a tranzakciós költségek A tárgyalás európai oldalról sikertelenül zárult, mett a két pontból egy sem kerïlt be a jegyzốkönyvbe

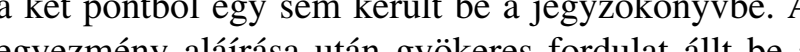

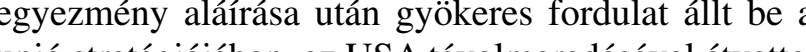

A volt „keleti blokk” átmeneti gazdaságai (köztük lékos csökkentést az 1985-87-es bázisidőszakhoz ké-

kellóen alacsonyak). A coase-i szemlélet szerint az extern hatás háttérben az áll, hogy a légkörnek nincsen pontosan definiált tulajdonosa, így szennyezésének kérdésében sem kompetens egy kijelölt személy vagy szervezet.

A helyzet megoldására létrehozták az emissziókereskedelmi rendszert, ebben a légkör tulajdonjoga helyett a szennyezés joga van meghatározva. A szennyezés jogát egy kereskedhetó értékpapír testesíti meg, amely egy tonna szén-dioxid kibocsátására jogosít. A szennezési egyégetkel való kereskedés biztosítja a A szennyezési egységekkel való kereskedés biztosítja a

Ha egy cég a piacon többet kap a szennyezési egységért, nint amennyit keres a szennyezést okozó tevé-

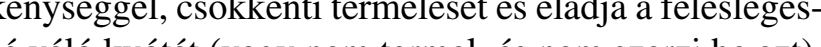
sé váló kvơtát (vagy nem termel, és nem szerzi be azt). szenceréli, szintén értéket teremt, hiszen a korábbihoz képest elég evesebb kvótával rendelkeznie. A piac hatása kettős. egyrészt ott valósul meg a szennyezésmegtakarítás vagy -csökkentés, ahol a legolcsóbb (zérus tranzakciós költséget feltételezve), másrészt a kvóta ára megfigyelhetővé válik és beépülhet a vállalati döntéshozatalba.

Az európai kvótakereskedelmi rendszerben az államok évente felülról meghatározzák a kibocsátható mennyiséget, és ennek megfeleló kvótét bocśt ki, amellyel szo $\mathrm{ki}$, allyel szabe). Ennek ályozend bályozk hoz képest az az elónye, hogy az emissziós kvotak mennyisége adott, ennek kovetkeztében a teljes kibocsátás feluulrố korlátos. Hátránya ugyanakkor az, hogy a kibocsátást sújtó adókkal szemben a vállalati oldal teljes megfelelésének költsége nehezen tervezhetô. A kvótaár a piaci viszonyok függvényében változik, az idôszak elején a piaci szereplốk nem tudják megmondani, hogy mennyi lesz a teljes megfelelésük költsége.

\section{Az emissziós kvóták tipusai}

A kiotói jegyzókönyv alapegysége az AAU (Assigned Amount Unit), amely egy tonna szén-dioxid légkörbe bocś́tán, amely egy ton az szenn-dioge az EUA (EU Allowance), a ely valón egységém á́ EUA (EU Allo jou cínkézelt AAU- Allowe felter gek mellett még két kiotoi egység érdemel említést: a CER-(Certified Emission Reduction) egységek a megvalósult tiszta fejlesztési mechanizmusokból (Clean Development Mechanism) keletkeznek, melynek során egy fejlett (Annex I) országbeli beruházó valósít meg egy emissziócsōkkentést eredményezó projektet egy fejlódö (nem Annex I) országban. A tényleges megtakarítás hitelesítése után bocsátják ki a CER-egységeket, melyek szintén piacképesek.

VEZETÉSTUDOMÁNY

Az ERU- (Emission Reduction Units) egységek két hogy a fejlódő országok mostani emissziója a rendelfitt (Ann-x I) ország kózöt negvalosulo, megtakarítást eredményezô közös megvalósítás projektekben jönnek létre. A kettős elszámolás elkerülése céljából keletkezésükkor azonos mennyiségú AAU-egységet semmisítenek meg.

EU ETS mérete, kiterjedése

$\mathrm{Az}$ európai emissziókereskedelmi rendszer (EU ETS) az elsố nemzetközi, szén-dioxid-kibocsátási egységeket forgalmazó rendszer. Hozzávetốlegesen 10.500 létesítmény összesen kétmilliárd tonna szén-dioxid-emisszióját fedi le az EU 27 országában és a három társult államban (Izland, Lichtenstein, Norvégia). A jelenlegi rendszer az üvegházhatást okozó gázok közül szinte kizárólag a szén-dioxidot fedi le. A kivételt a Norvégiában é Hollandiában kibocsátott dinitrogén-oxi adja (European Commission, 2009), de ennek mértéke nem jelentós.

Erdemes az EU ETS által lefedett teljes emissziómennyiséget a globális kibocsátáshoz hasonlítani. Az adatok öszszemérhetôségét nehezíti, hogy az egyes országkategóriák (fejlett, fejlődô) egébe országk más idôszakra

A fejlett (Annex I) országok teljes kibocsátása 2007-ben 18,1 milliárd tonn

szén-dioxidnak felelt meg (UNFCCC,
Flexible Queries 2010), ebbốl 5 milliárd tonna köthetố $\quad$ repel a kereskedelmi rendszerben. A kvótaegységre esố az EU(27)-hez. A 122 fejlődó (nem Annex I) ország tranzakciós költségek minimalizálása érdekében fontos, kibocsátása 1994-es adatok alapján 11,7 milliárd ton- hogy elsősorban a legnagyobb kibocsátást okozó létena szén-dioxidnak felel meg (UNFCCC, 2005). Az sítmények kerüljenek a szabályozás hatálya alá. A rendEU ETS relatív méretét a 2009-es allokált mennyiség szerbe (egyelóre) nem kerültek be a jelentős összesített (CITL, 2010) alapján vettem számításba.

EU ETS relatív mérete

\begin{tabular}{|lccc|}
\hline & $\begin{array}{c}\text { Kibocsátás } \\
\text { ezer tonna } \\
\text { CO2 }\end{array}$ & $\begin{array}{c}\text { Elózõ } \\
\text { kategóriához } \\
\text { képest }\end{array}$ & $\begin{array}{c}\text { Teljes } \\
\text { kibocsátához } \\
\text { képest }\end{array}$ \\
Teljes & 29847563 & - & $100,00 \%$ \\
Annex-I & 18112126 & $60,68 \%$ & $60,68 \%$ \\
EU(27) & 5032232 & $27,78 \%$ & $16,86 \%$ \\
EU ETS & 1967387 & $39,10 \%$ & $6,59 \%$ \\
\hline
\end{tabular}

A 1. táblázat kibocsátási adataiból látható, hogy a jelenleg legnagyobb emissziós piac az EU(27) teljes kibocsátásának 39,1 százalékát, a Föld teljes kibocsátásának mindössze 6,6 százalékát fedi le. Ha feltesszük, kibocsátást okozó, de nagyszámú kibocsátót tartalmazó láblázat szektorok, erre két tipikus példát lehet hozni: az kezésre álló 1994-es adatoknál magasabb, akkor az EU
ETS részesedése ennél is kisebb.

\section{Lefedett iparágak}

Ha arra a kérdésre keressük a választ, hogy az eukötốdik, akkor az EU(27) 61 százalék milyen iparágakhoz érdemes szemügyre venni. Amint a 2. táblázatban látha-

(par) kibocś́táśnak (ezer tonna $\mathrm{CO}_{2}$ iparági bontása, energia részletezve

A.2 Gyár- és építõ ipar

. Egyéb (máshol nem említett) források $\quad 10395$ B Megszökõ emisszió üzemanagyokból $\quad 86644$ Energia felhaszn

Oldószerek és egyéb anyagok felhasználása $\quad 12356$ 6̈̈ldhasználat és erdõgazdálkodás $\quad 461386$

141135 Egyéb

625291

szektorok, erre két tipikus példát lehet hozni: az si forrás bocsát ki összesített szinten jelentôs mérsi forrás bocsát ki osszesített szinten jelentôs mérközel gymilliárd tón gáz (2007-es adatok alapján kózel egymilliárd tonna szén-dioxidot képvisel), a másik terület a lakossági szféra fosszilis eredetû́ fứése. Szintén le nem fedett terület a mezógaz

sagg közel félmilliárd tonnás kibocsátásával.

Természetesen azt nem jelenthetjük ki, hogy ezek a területek a szabályozásból teljes mértékben kimaradtak, ugyanis az egyes országok a jegyzőkönyvben a teljes kibocsátásukra vállalták a csökkentési szinteket. Bár az államszintú célokat egyéb szabályozói eszközökkel is elố tudják segíteni (például jövedéki adó z üzemanyagokra, szigetelési követelmények elôírása)

\section{VEZETÉSTUDOMÁNY}


azonban szerencsés lenne, ha a létező szén-dioxid-költség általánosabb mértékben be tudna épülni a gazdaságban létezó árakba, ez pedig az emissziókereskedelm rendszer bővítése mellett szól (ebbe az irányba mutat repülési szektor tervezett bevonása is

\section{A megfelelés szabályai}

Az EU ETS-ben levő, elszámolásra kötelezett vállalatok speciális elszámolási követelményekkel szembesülnek. A kvóták kínálatát a nemzeti hatóságok adjuc,

resztül értékesíteni. Zérus tranzakciós költségek esetében a kvótaallokáció módja (ingyenes kiosztás vagy allokáció) nem befolyásolják a rendszer hatékonyságát (Lesi - Pál, 2004: 27. o.).

Az emissziós kvóták ingyenes kiosztása minden év február végéig történik meg. A vállalat a tény kibocsátásáról a következő év március 31-éig köteles jelentést tenni, április 30-ig pedig az elfogadott mennyiségnek megfelelô számú kvótát kell visszaadnia az illetékes hatóságnál. Az elszámolási idôpontokat az 1 ábra szemlélteti:

\section{Az EU ETS elszámolási idốpontjai}

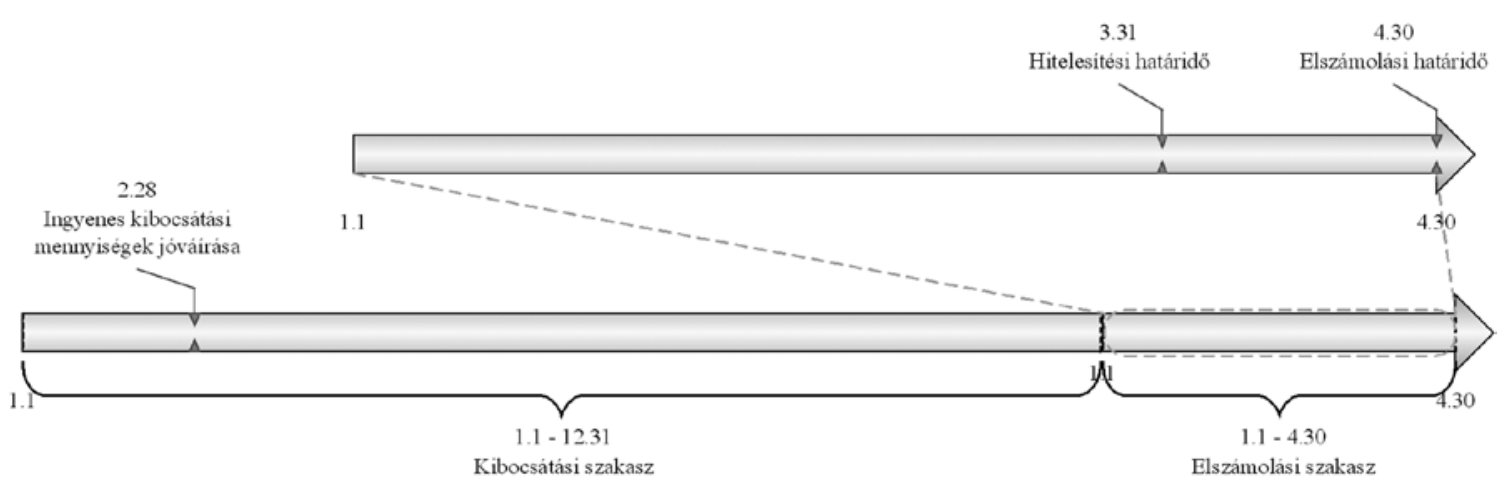

amelyek a jelenlegi rendszer szerint túlnyomórészt ingyenesen juttatják a kibocsátási egységeket az elszámo-

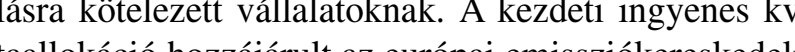
taallokáció hozzujôn rendszer piaci szereplokkel való elfogadtatásához: a kötelezett vallalatok számána a rendszerbe való belépés nem okozott hirtelen jelentôs nêttekn költségennelkedést, foleg ha a szén-dioxid-adó alternatívájához viszonyítunk.

Az ingyenes juttatás alternatívája az aukció, amelyre a tagországok meghatározott mértékig engedélyt kaptak. Az elsố idôszakban Magyarország három más EU-taggal együtt élt ezzel a jogával, és 2006-2007-ben közel 2,4 millió egységet értékesített, mely a teljes mennyiségünk 4 százalégünk 4 százalékát tette ki (FaA tervek A tervek szenint hosszabb távo az ingyenes kiosztás háttérbe fog szorulni és a kvótákat növekvő részarányban fogják aukciókon ke-
Meg nem felelés esetén (a vállalat nem tudja kibocsátását lefedni kibocsátási egységekkel) egyrészt ként az els" kereskési szakaszan 40 euró, a kiotói szakas 100 eú bintetést kell fizetne. Ha teles kibocs 100 enó bis

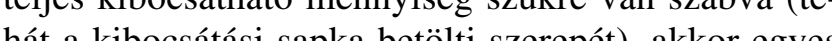

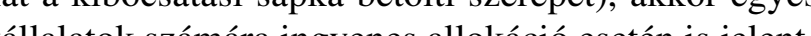
villalo het többletköltséget a megfelelés (kibocsátással való elszámolás). A helyzet megvilágítására érdemes megnézni a 2009-es allokacio es teny kibocsátások viszonyát (3. táblázat).

ocsátás (tonna $\mathrm{CO}_{2}$ ) viszonya iparáganként

3. táblázat Adatok: CITL

\begin{tabular}{|l|rr|rr|}
\hline \multicolumn{1}{|c|}{\begin{tabular}{c} 
2009-es allokáció és emisszió \\
\multicolumn{1}{|c|}{ összehasonlítása }
\end{tabular}} & Allokált kvóta & \multicolumn{1}{c|}{ Emisszió } & \multicolumn{2}{c|}{ Eltérés } \\
\hline Erõmûvek & 1262724431 & 1377050410 & 114325979 & $9,1 \%$ \\
Mész, cementgyártás & 213812116 & 151500790 & -62311326 & $-29,1 \%$ \\
Vas- és hengermûvek & 185023065 & 95497313 & -89525752 & $-48,4 \%$ \\
Kõolaj finomítók & 153631664 & 146207672 & -7423992 & $-4,8 \%$ \\
Papír, csomagolóanyag gyártás & 38843044 & 27895891 & -10947153 & $-28,2 \%$ \\
Üveggyártás & 25562614 & 19389552 & -6173062 & $-24,1 \%$ \\
Kokszolók & 22409275 & 15757371 & -6651904 & $-29,7 \%$ \\
Hulladék hasznosítók & 21994645 & 11032618 & -10962027 & $-49,8 \%$ \\
Téglagyártás & 19214819 & 9093890 & -10120929 & $-52,7 \%$ \\
Egyéb & 24171588 & 19884996 & -4286592 & $-17,7 \%$ \\
\hline Összesen & $\mathbf{1 9 6 7 3 8 7 ~ 2 6 1}$ & $\mathbf{1 8 7 3 3 1 0 5 0 3}$ & $\mathbf{- 9 4 4 0 7 6 ~ 7 5 8}$ & $-4,8 \%$ \\
\hline
\end{tabular}

VEZETÉSTUDOMÁNY ovábbgörgetik az adottévi hiáný́t, másrést tonnán-
Havi kereskedett mennyiség alakulás Adatok: PointCarbon

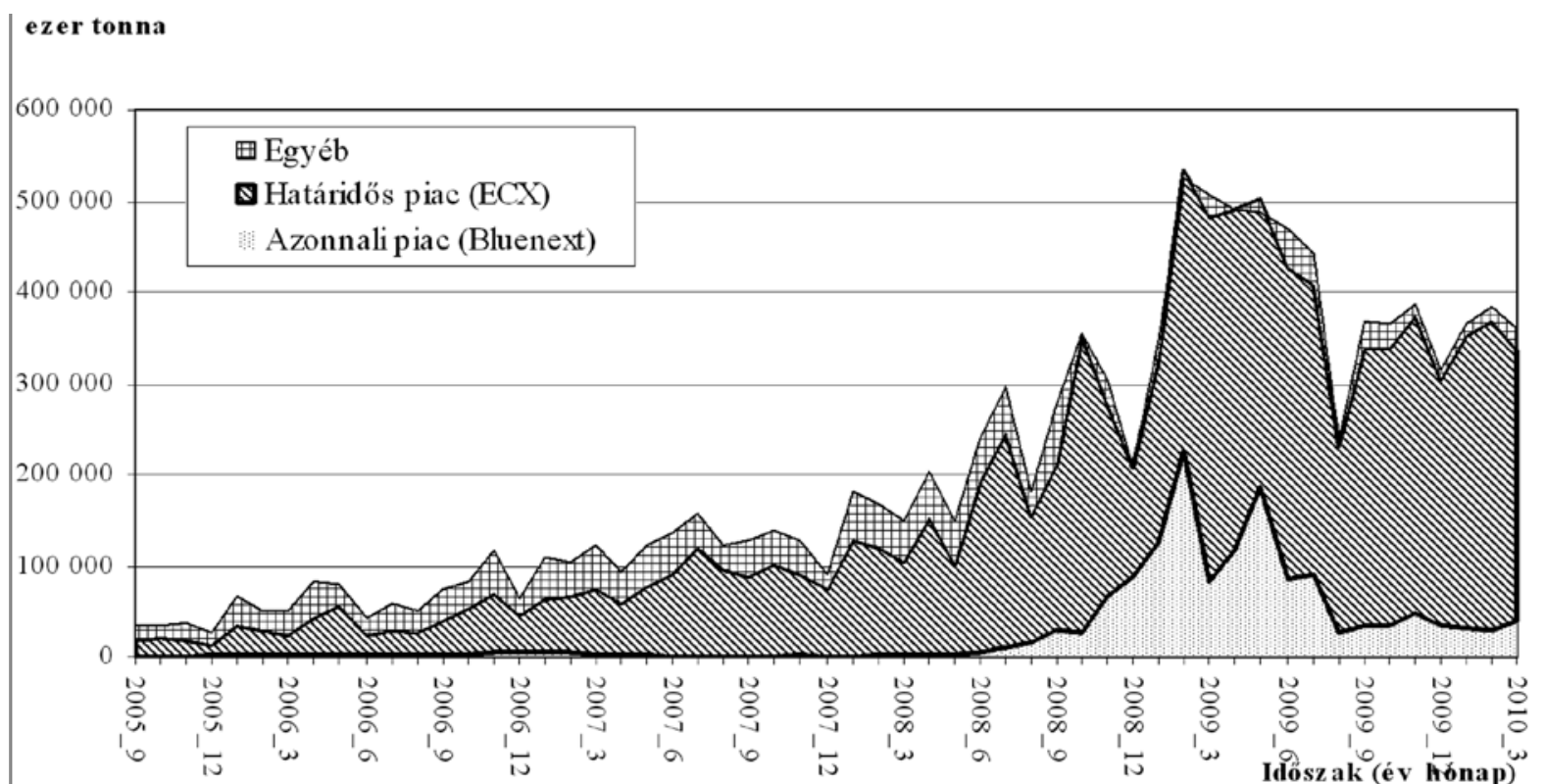

2009-re összesen 1,97 milliárd tonna szén-dioxidkvótát adtak oda a vállalatoknak, a tényleges emisszió (részben a válság miatt) mintegy 94 millió tonnával latta maradt az alloḱlt mennyiségnek. A kibocsátot és allólt menniség killö es allokitt az a az erôna vek estéc ki, mint amennyi kvótát kaptak). Kissé leegyszerúsítve megállapítható, hogy az erômúvi szektornak többletköltséget, a tobbi szektornak tobbletbevételt hozott kereskedelmi rendszer. A jelenség mögött az a szándék húzódhat meg, hogy a legnagyobb, és elsősorban az európai piacra termelô szektort - a villamos erómúveket próbálják olyan helyzetbe hozni, hogy kénytelen legyen kalkulálni a szén-dioxid árával, és így kibocsátás-csökkentố beruházásokat megvalósítani. A többi, kevésbé helyhez kötött iparágat ugyanakkor lényegében nem terheli a szén-dioxid költsége, és így versenyképes tud rendszeren kívül esó országok vállalataival.

\section{Kereskedési adatok}

Az EU ETS 2005-ben indulva három évvel elózte me a kiotói vállalások tárgyát képző 2008 és 2012 közötti időszakot. Ehhez igazodva a kereskedelmi rendszert két szakaszra bontották: az elsố szakasz (Pilot Phase) 2005-2007-ig tartott, szerepe elsôsorban a tapasztalatszerzés volt, a jelenleg is zajló második kiotó szakasz (2008-2012) hivatott biztosítani a vállaláso költséghatékony teljesítését.

\section{VEZETÉSTUDOMÁNY}

A kvótapiac az EU ETS indulása után gyors növekedésnek indult. A havi kereskedett mennyiség és a forgalom megoszlása a 2. ábrán látható.

Ot év alatt a kereskedett mennyiség megtízszereződött: a vizsgált idôszak elején a teljes piacon havonta 35 millió tonna szén-dioxidra vonatkozó kvóta cserélt gazdát, 2010 márciusára az érték 361 millió tonnára emelkedett, 20 eurós tonnánkénti emissziós egységárat feltételezve, ez havi 7,2 milliárd eurós piacot jelent.

A tranzakciók legnagyobb része a határidôs szekcióban zajlott, melynek oka elsősorban az lehet, hogy határidôs pozíciók nyitása az azonnali ügyletekkel szemben nem igényel jelentősebb pénzösszeget ugyanis csak az ügylet lejáratakor kell kifizetni a kvóa vételárát, a futamidô alatt elég az aktuális letéti követelményeknek eleget tenni). Azok a kvótapiaci szereplók akik nem tartoznak az EU ETS hatálya alá (ilyenek pécíl a polok vagy spekulánok) jellenzón szintén magas tókeátté-

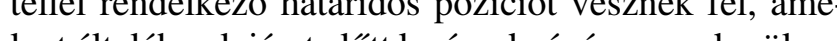
lyet általában lejárat elốtt lezárnak, és így nem kerül sor kvóta tényleges leszállítására.

A forgalom után vessünk egy pillantást az emissziós kvóták áralakulására. A 3. ábrán a Bluenext (azonnali árak) és az ECX (határidős ügyletek) tôzsdékrố származó, 2005. június és 2010. május közötti záró-, letve elszámolóarak alakulását ábrázoltam. A határidôs ár szerepeltetésére azért volt szükség, mert segítségével az elsó és második kereskedési szakaszra 
vonatkozó árak könnyebben öszszehasonlíthatók (a határidos árakban levó hozamtól eltekintettem (3. ábra).

Amint látható, 2006 márciusáig a két kereskedési szakaszra vonat kozó ár viszonylag együtt mozgott. 2006 áprilisában hatalmas áresés következett be a kvóta azonnal piacán (a leértékelődés mértékét jól szemlélteti, hogy április 27 én egy nap alatt 43,7 százalékka csökkent a kvóta zár 7 százalékkal csökkent a kvóta záróna). A gyo uitemú érékvesztes oka az volt, ogy ekkor kentlek nyilvánosságra az elsố tényleges kibocsátást bemutató adatok. A piaci szereplók számára egyre nyilvánvalóbba vált, hogy az első idôszakban töb kvótát osztottak ki, mint amennyi a vállalatok tényleges kibocsátásának lefedéséhez szükséges.

Ez a jelenség rámutat a cap and trade rendszer egyik sajátosságára: ha a kvótát túlosztják, akkor a kvóta elértéktelenedik, és nem hat ösztönzóleg a kibocsátás csökkentésére. Mivel a 2005-2007-es idószakra vonatkozo kvótákat, csekély kivételtól eltekintve (lás Convozo kvóákat, csekél a kivételtô eltekinge (lásd Convery Redmon, 2007), csak az adott kereskedesi szakaszba lehetett felhasznalni, az esellegesen feleslegessé váló, elsó periódusra vonatkozó kvơták a 2007-es idósz elszámolâsa után êtekunket vesztették.

A hirtelen âresés mellett a másik érdekes jelenség az volt, hogy az elsố idôszakra vonatkozó ár elvált a második időszakra vonatkozótól (ez utóbbi a kezdetben mé csak határidós piacon létezett). Ellerman és Parson (2006) a két idốszakra vonatkozó árból valószínúségre vonatkozó változót vezetett le. A mutató mögött az feltételezés áll, hogy ha a lejáratkor kvótafelesleg van piacon (túlosztás), akkor a kvóta értéktelen (ára nulla), ha kvótahiány van, akkor arbitrázsmentes piacot feltételezve az első időszzkra vonatkozó kvóta (EUA annyit fog érni, amennyit a meg nem felelés attos-a annyit fog éni, amz 40 eurós büntetés). Az eno iclus).

Az elsố ilôszakra vonatkozó kvótaár a különbözó alternatívák értékei és a valószínúségek segítségév számítható:

$E U A_{05-07}=P($ túlosztás $) \cdot 0+P($ kvótahiány $) \cdot\left(A U A_{08-12}+40\right.$

$P($ túlosztás $)+P($ kvótahiány $)=1$

A 2007. év végi kvótahiány esélyét mutató Parsons mutatót a képlet atrendezésével kapjuk meg:
Emissziós kvóta áralakulása

Adatok: Bluenext, ECX

Emissziós kvóta (EUA) áralakulása

3. ábra

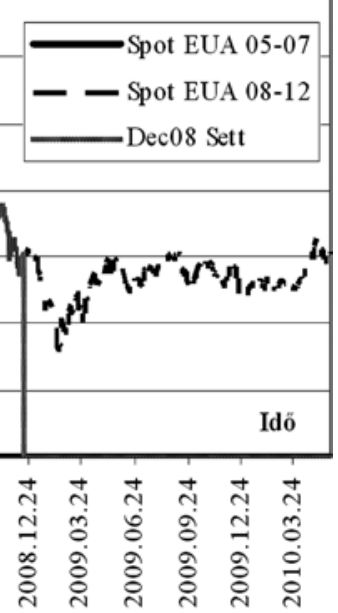

Parsons-mutató $=P($ kvótahiány $)=\frac{E U A_{05-07}}{E U A_{0 s-12}+40}$

A 2008-2012-re vonatkozó második (kiotói) szakaszban engedélyezték a „bankolást”: a vállalatok fel nem használt kibocsátási egységeiket átvihetik a harmadik szakaszba. A kvótafelesleg alternatívájához tartozó ár ettôl kezdve nem nulla, hanem a következő időszak hasznositási lehetőségeinek értékétól függően pozitív, így a Parsons-mutató jelenlegi formájában érvényét veszti.

\section{Vállalati kockázati faktorok}

Az emissziós egységek piaca jelentốs mérettel és növekvő súllyal rendelkezik. A megfelelésre kötelezett vállalatok számára fontossá vált az EU ETS-hez kapcsolódó pénzügyi kockázat ismerése és hatékony kezelése. A szabályok szerint a megfelelésre kötelezett cégeknek a ténykibocsátásuknak megfeleló mennyiségú kvótát kell visszaadniuk az illetékes hatóságoknak. Az elszámoláskor (kibocsátással megegyezó számú kvóta visszaadásor (kibocsátással megegyezó szés a kibocsátási egységek abszolút száma a lényeges, hanem a kettő relatív viszonya, melyrốl a vállalat nettó pozíciója árulkodik. A vállalat nettó pozíciója (NP) megmutatja, hogy a kvótában felvett pozícioja (Q) mennyivel nagyobb a kibocsátásánál (Em):

\section{$N P=Q-E m$}

A pozíció long (kvótatöbblet), amennyiben több kvótával rendelkezik, mint kibocsátási egységgel (Q $>$ Em), és short (kvótahiány), ha a meglevố kvótái nem nyújtanak fedezetet a kibocsátására $(\mathrm{Em}>\mathrm{Q})$.
Nettó pozíciót változtató faktorok

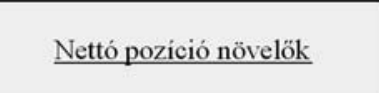

Nettó pozició csökkentök

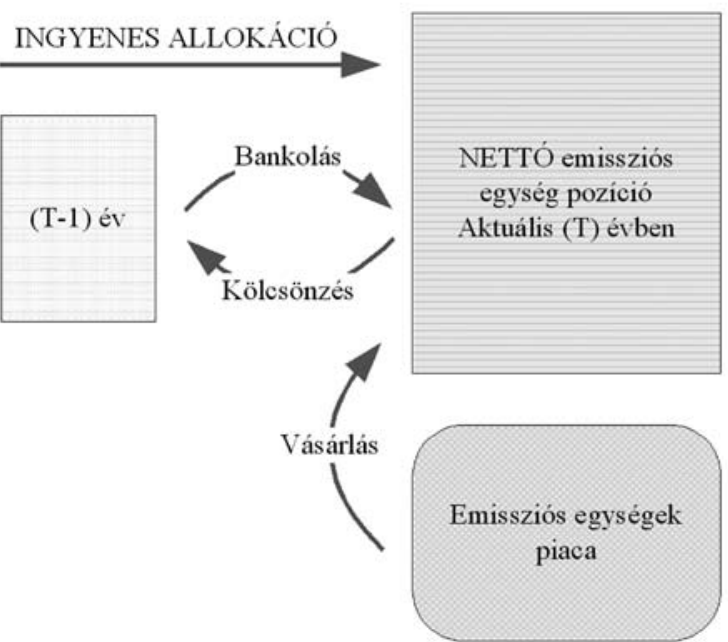

Az elszámoláskor leadandó kibocsátási egységek többféle forrásból származhatnak. A jelenlegi rendszerbe a térítésmentesen kapott emissziós egységek képviselik a rendelkezésre álló kvóták legnagyobb részét. Emellett fel lehet használni elôző időszakról megmaradt (bankolt), illetve a következó időszakról előrehozott (kölcsön vett) emissziós egységet is. A vállalat a kvótapiacon emissziós egységeket adhat-vehet, amely tovább módosítja az elszámoláskor rendelkezésre áló egységek mennyiségét.

A nettó pozíciót változtató faktorokat a 4. ábra mutatja (a nettó emissziós egység pozíció felé mutató nyilak növelik annak értékét, a kifelé mutatók csökkentik) (4. ábra).

Pénzügyi szempontból, a megfelelés szabályait tekintve, az EU ETS rendszerébe tartozó vállalat a következó kétfajta kockázati elemmel szembe

- a kibocsátás mennyiségének bizonytalansága: év közben nem tudja pontosan meghatározni, hogy adott év alatt hány tonna szén-dioxidot fog a levegóbe bocsátani, így azt sem tudja megmondan hogy a következő év áprilisának végén mennyi kvótát kell visszaadnia a hatóságnak,

- a kvótaár bizonytalansága: a vállalat nem tudja, hogy a késóbbiekben milyen áron tudja beszerezni/eladni a szükséges vagy felesleges kvótáit.

Az idố elórehaladtával az elóbbi kockázati elemek csökkennek: a vállalat teljes éves kibocsátásának egyre nagyobb hanyada valik ismertté és egyre kisebb részét
4. ábra kell elóre jeleznie, állandó éves szórást feltételezve csökken a jövóbeli volatilitású árfolyammodell alkalmazása esetén (ilyenek például a GARCH-modellek) ugyanakkor előfordulhat, hogy egy kockázatosabb időszak után az idôben elórehaladva a jövóbeli árfolyam bizonytalansága növekszik.

\section{A várható kibocsátás}

\section{bizonytalansága}

A vállalat év végi várható kibocsátása bizonytalan, ezért egy valószínüségi változóval jellemezhetô. Kockázatkezelési szempontbó a jövốbeli kibocsátás sứrúségfüggvényére van szükségünk, amely rendelkezik várható kibocsátást mutató várható értékkel, és a bizonytalanságot képviselố szórással. A függvény alakja az egyes esetek bekövetkezésének valószínúségét adja meg. Osszuk fel az időszakot (példánkban legyen egy év) n darab egyenlő hosszúsáqú periódusokra (például napokra). Azév végi halmozott kibocsútás megkapható periódusokban levố kibocsátások összegével:

$$
\text { Emmiszió }_{\dot{E} V E S}=\sum_{i=1}^{n} \text { Emisszió }_{i}
$$

Év közben (t-edik periódus után) az év végi kibocsátás várható értéke a következók szerint fog alakulni:

$E\left(\right.$ Emisszió $\left._{\dot{E} V E S}\right)(t)=$

$$
\begin{aligned}
& \sum_{i=1}^{t} \text { Múltbeli Tény Emisszióó } \\
& \qquad \sum_{i>t}^{n} E\left(\text { Jövöbeli Emisszió }{ }_{\text {PERLÓDUS }}\right)_{i}
\end{aligned}
$$

A vállalati kibocsátás bizonytalanságát alapvetốen A vóoiai és piaci faktorokkal lehet magyarázni. Az cóbbiek a várható iizemzavarokra és leállásokra Az utóbbiak a nyersanyag és termék áralakulásaira vonat-

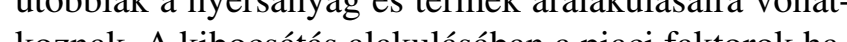
koziak. A jecocsás alakulásában a piaci faktorok hasź tánú szzentós, ha a vallalat teljes kapacitását hoszszú távú szerzôdések fedik le, termelési kötelezettségei vannak. Ebben az esetben a piaci árakon nem múlik a termelési, és ezen keresztül a kibocsátási mennyisége. A továbbiakban először kizárólag technológiai bizonytalanságot feltételezve független normális eloszlásokkal modellezzük a várható emissziót. Ezután a piaci aktorok által okozott bizonytalanságot szimuláció segítségével vetítjük elöre.

\section{VEZETÉSTUDOMÁNY}


A kibocsátás alakulása független

normális eloszlású kibocsátás esetén Ha feltesszük, hogy a periódusok kibocsátásai azonos eloszlásúak, függetlenek egymástól, várható értékük: $\gamma$, szórásuk: $\delta$, akkor a jövóbeli halmozott emisszió is normális eloszlású, a következô paraméterekkel (összesen $n$ periódus van, jelenleg a t-ediknél tartunk):

$\sum_{l \backslash t}^{n} E\left(\text { Jövöbeli Emissziió } \text { PERIÓDUS }_{1}\right)_{l} \approx$

$$
N((n-t) \cdot \gamma, \sqrt{n-t} \cdot \delta)
$$

Mivel a tény emisszió szórása nulla (teljesen biztos), az éves emiszszió eloszlását megkaphatjuk, ha az elóző eloszlás átlagához hozzáadjuk a tényemisszió értékét.

$E\left(\right.$ Emisszió $\left._{\text {EIES }}\right) \approx N($ Tényemisszió $+(n-t) \cdot \gamma, \sqrt{n-t} \cdot \delta)$

Az idôben előrehaladva $(\mathrm{t} \rightarrow \mathrm{n})$ az éves emisszió bizonytalansága csökken, az eloszlás szórása nullához tart (mert $\sqrt{n-t} \rightarrow 0$ )

Ha feltesszük, hogy az allokáció, az előző idôszakról félretett (bankolt) kvóta, a piaci tranzakciók nem rendelkeznek mennyiségi kockázattal (vagy teljes mértékben külső adottságok, vagy a vállalat döntéskörébe tartoznak), a kibocsátási egységek (kvóták) várható nettó pozíciójának eloszlása egyenló lesz a kibocsátás eloszlásának ellentettje és a többi tétel (allokáció, bankolás, stb) hatásainak összegével:

E(Nettó pozíción $\left.{ }_{\mathrm{EVES}}\right) \approx$

N(Allokáció+Bankolás+Tranzakciók Tényemisszió $-(n-t) \cdot \gamma, \sqrt{n-t} \cdot \delta)$

Tételezzünk fel egy példát, melyben az évet 365 napra osztjuk fel és a 180, 270, illetve 330-dik napon vizsgáljuk a várható éves kibocsátás alakulását a 4 . táblázat paraméterei és számítási eredményei szerint.

vállalati emisszió sứrúségfüggvényének idốbeli alakulása ormális eloszlást feltételezve egyszerúség kedvéért tegyük fel, hogy a vállalat nem készletez, a beszerzett tüzelóanyagot Tételezzük fel továbbá azt is, hogy a vállalati tevékenységben nincsen szezonalitás, és a vállalat a piachoz képest kicsi (árelfogadó, a tevékenységének szintje nincs hatással az árakra). A vállalat profitja kifejezhetố egységnyi emisszióra vonatkoztatva. Ennek számításához szükségünk van a termék szénintenzitására $(\delta)$, amely az egységnyi termék elóállításakor keletkező szén-dioxid mennyiségét mutatja, értéke adott technológia esetén a feltételezés szerint fix. A mérôszám a tüzelőanyag karbon intenzitás (I), a termikus hatékonyság (e) és a csővégi tisztítási arány (c) segítségével számítható, a következók szerint:

$$
\delta=I \cdot \frac{(1-c)}{e}
$$

Ha S paraméterek jelzik a megtermelt áram, energiahordozo- és kvótaárakat, az OVC pedig a termékegységre eső egyéb változó költségeit, akkor a termelés feltétele a következô (részletesen lásd Nagy, 2010b):

Egységnyi kibocsátásra jutó termelési fedezet $=$

$$
\frac{1}{\delta}\left(S_{\text {Aram }}-\frac{1}{e} S_{\text {Energihhorloso }}-O V C\right)-S_{E U A}>0
$$

Az elóbbi képlete hasonlít az erómúvi szektorban elterjedt spread fogalomra (Alberola - Chevallier Chèzec, 2008). Clean spark spread a gázturbinás erốmúvekben megtermelt egy MWh energián realizá kvóta árát is tartalmazó fedezetet jelenti. A spread és levezetett fedezet képlet között két lényeges különbség van: egyrészt a képletben a fedezet nem a termelésre, hanem a kibocsátásra van vetítve, másrészt tartalmazza az egyéb változó költség(OVC)tagot. A fedezet és spread fogalmakhoz kapcsolódóan fontos hangsúlyozni, hogy míg az alaptermék (áram, energiahordozo, EUA) piaci árai minden szereplő esetében azonosak EUA) pio ïzemek eltéró technológiai paraméterokk az egyes úreme múködnek, így az egységnyi kibocsátásra esô termelési
fedezetük eltér.

A termelési feltételben a technológiai paramétereket a modellezési idótartam alatt állandónak tétele tük fel, az alaptermék árak ugyanakkor sztochasztikus valószínúségi változók. A továbbiakban összefoglalóan bemutatjuk, hogyan lehet levezetni a vállala emissziót.

Hozzuk létre döntési változót, amely 0 vagy 1 értéket vehet fel attól függően, hogy a vállalat egységn kibocsátásra jutó termelési fedezete milyen elôjelî́
$\Phi=\left[\begin{array}{lll}0 \text { ha } \frac{1}{\delta}\left(S_{\text {Temmike }}-\frac{1}{e} S_{\text {Energiahordosos }}-O V C\right)-S_{E U A} \leq 0 \\ 1 \text { ha } \frac{1}{\delta}\left(S_{\text {Temmik }}-\frac{1}{e} S_{\text {Energiahorodosos }}-O V C\right)-S_{E U A}>0\end{array}\right]$

A napi döntési változó $(\Phi)$ megfeleltethetó egy egzotikus, három alaptermékre vonatkozó, európai típusú, bináris opció kifizetésfüggvényének. A döntési változô várható értéke megegyezik az opció értékével, annyi megkötéssel, hogy egyrészt kifizetésfüggvényét nem kell a jelenre visszadiszkontálni, továbbá az opciós ertékeléséńl szokásos módszentan toven szemen apciós

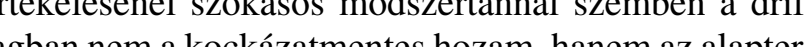
ć́k hoz alapterëkek hozama szerepel. A t-edik napra vonatkozó napi értékek és a valószínúségek szorzataként is:

$E(\Phi[t])=0 \cdot P($ Termelési fedezet $(t) \leq 0$

$+1 \cdot($ Termelési fedezet $(t)>0)$

$=P($ Termelési fedezet $(t) \leq 0)$

Amint látható, a változó várható értéke megegyezik nnak a valószínúségével, hogy a termelési fedezet pozitív lesz. Az időszaki emisszió modellezése érdekében vezessük be a halmozott döntési változót $(\Omega)$, amely Tidőszak alatti termelési döntések halmozott értékét mutatja:

$$
\Omega(T)=\sum_{t=1}^{T} \Phi_{t}
$$

Ha termelés esetén egy nap alatt a vállalat állandó (c) mennyiségú szén-dioxidot bocsát a légkörbe (âllás esetén semmit), akkor T időszak alatti várható kibocsátása az alábbi lesz:

$E(\operatorname{Em}(T))=c \cdot \Omega(T)=c \cdot \sum_{t=1}^{T} P($ Termelési fedezet $(t)>0)$

Az emisszió jövőbeli értékének modellezésére a sztochasztikus pénzügyekben elterjedt eszközök alkalmazhatók. A modellezési problémát nehezíti, hogy a modellben megengedjük az alaptermékek hozamai köötti korréción. A szerző́ korábi munkáiban a témáKon-Millor-f́́te multinomí́lis fa módszerét (Nagy,

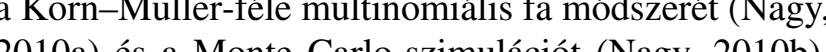
(Nagy, 2010b). Atobbdimenziós, korrelációt is tartalmazó Monte Carlo szimuláció elméleti háttere és részletes ismertetése az említett munkában található, a jelen cikkben csak az új futtatás kiinduló paramétereit és a szimuláció eredményeit mutatjuk be

A modellben egy gázturbinás erơmú szerepelt, a övetkező technológiai paraméterekkel, amelyek az 5. táblázatban találhatớk.

\section{VEZETÉSTUDOMÁNY}


Technológiai paraméterek

\begin{tabular}{|llr|}
\hline \multicolumn{1}{|c}{ Paraméter } & \multicolumn{1}{c}{ Dimenzió } & Érték \\
Tüzelõanyag szén intenzitása (I) & tCO2_kibocsátott/MWh_bemenõ & 0,2014 \\
Termikus hatékonyság (e) & MWh_kimenõomWh_bemenõ & $38 \%$ \\
Csõvégi tisztítási arány (c) & tCO2_megkötött/tCO2_termelt & $0 \%$ \\
Termelt telektromos energia szén intenzitása (ä) & tCO2 kibocsátott/MWh kimenõ & 0,5300 \\
Egyéb válttozó költség (OVC) & EUR/MWh kimenõ & 3 \\
\hline
\end{tabular}

A szimuláció alapján az emiszszió várható ér$\begin{array}{llr}\text { téke } & 31.778 \text { ton- } \\ \text { na, } & \text { a } & \text { szimulált }\end{array}$ sưrúségfüggvény alakja teljesen eltér a Gauss-féle haranggörbétôl: a véglet (150 nap

Amodellezéshez szükséges három alaptermék áradatai nyilvánosan hozzáférhető forrásból származnak:

- áram azonnali rendszerára: 2008. 01. 01 - 2010.

07. 31, Nordpool

- gázár azonnali ára: 2008. 03. 05 - 2010. 07. 31

Nordpool

- emissziós kvóta (EUA) azonnali ára: 2008. 02. 26

-2010. 07. 30 Bluenext.

A szimuláció indulóárai a 2010. 07. 30-án érvénye árak voltak, ezek és a historikus árakból számított logaritmikus napi hozamok statisztikái a 6 . táblázatban szerepelnek.

Alaptermékek árfolyam-alakulásával kapcsolato kiindulási paraméterek

\begin{tabular}{|lclr|lr|}
\hline & Hozam & Szórás & Induló ár & \multicolumn{2}{|c|}{ Korreláció } \\
Áram & $-0,000223$ & 0,070501 & 38,550 & Áram-Gáz & 0,027559 \\
Gáz & $-0,000279$ & 0,058578 & 18,425 & Áram-EUA & $-0,016272$ \\
EUA & $-0,001606$ & 0,025099 & 14,020 & Gáz-EUA & $-0,125647$ \\
\hline
\end{tabular}

latt egyáltalán nem termel - 0 emisszió) valószínú sége magas, aminek magyarázata az egymást követő napok döntéseinck függóségében rejlik. Mivel egy nap alatt a termékek és erófoŕások ́rai nem mozdulnak el jelentósebben, az adott napi terméćsi sz:intet na A szimulált sứrúséfoüügovény alakja többek közzës kiindulási egységnyi kibocsátásra esó fedezettól függ (ez a 2010. 07. 30-i idópontban erôsen negatív értékú volt: -38,43 EUR/ $/ \mathrm{CO}_{2}$ ). Ha az induló fedezet közelíti a nullát, a sưrúségfüggvény kád alakú lesz (a „sosem termel” és „,mindig termel” valószínúsége lesz kiemelkedó). Magas pozitív fedezet esetében viszont a kibocsátásra szelsôségesen jobbra ferde eloszlást kapunk

(a minden napon történő termelés a legvalószínúbb). A továbbiakban először kitériün a kvóta árfolyamelôszór kitérink a kvóta árfolyamkockzztén a két válla at jôn vállalat jövedelmezőségére.

\section{A jövóbeli kvótaá}

\section{bizonytalansága}

Amennyiben a vállalat az adott idốpillanatban több

A szimuláció 150 napra 50.000 futtatásra lett elvégezve, a kibocsátás modellezett gyakorisági függvénye a 6. ábrán. (n) rendelkezik, short pozíciója lesz kvótából (kvótahiány).

6. ábra Ebben az esetben a jốóben kibolefedésre. Amíg nem történik meg a vételi tranzakció, addig számára bizonytalan, hogy a vásárlás pillabiźńtan, hogy a ví sillanatur me

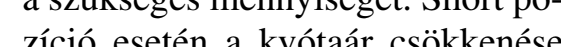
zíció esetén a kvótán csökkenése emeli nyitott (kockázatnak kitett) pozíciójának értékét (hiszen olcsóbban tudja lefedezni a tobblet kibocsátását), az áremelkedés hatása ezzel ellentétes.

Amennyiben a vállalat az adott ideig kevesebb üvegházhatású gázt bocsátott ki, mint amennyi kibocsá-

VEZETÉSTUDOMÁNY tási egységgel rendelkezik, az aktuális kvótapozíciója long (kvótafelesleg). Erre a szituációr jó példa az ingyenes allokáció utáni helyzet: a vállalat megkapta az éves kibocsátását nagy részben lefedô mennyiséget, amíg ténylegesen csak az év negyede telt el. Csökkenő árak esetében jobban járhatna, ha a jóváirás után eladná az összes felesleges kvótáját, majd a tényleges felmerülés pillanatában (alacsonyabb áron) visszavásárolná. Amennyiben a vállalat hoszszú ideig jelentős mértékú long pozícióval rendelkezik, és nyitott poź́ciójt nem fedezi, ak

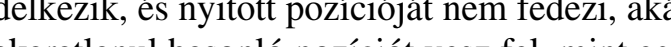
áremelkedésre fogadó spekuláns. áremelkedésre fogaró spekuláns.

Most vizsgaljuk ning, hogy a vállalat 2010 07. 30-1 pontból nézve várhatóan milyen kvótaárral fog találkozni 150 nap múlva. A kvóta jövớbeli árának eloszlására a pénzügyekben elterjedt lognormalitást tételeztük fel (Hull, 1999: 292. o.), azaz az árfolyamok logaritmusának eloszlása normális:

$$
\ln S_{T} \sim \mathrm{N}\left[\ln \mathrm{S} 0+\left(\mu-\frac{\sigma^{2}}{2}\right) T, \sigma \sqrt{T}\right]
$$

A T idô múlva levô árfolyam várható értéke és varianciája a következő képletek szerint alakul:

$$
E\left(S_{T}\right)=\mathrm{e}^{\mu T} \operatorname{var}\left(S_{T}\right)=S_{0}{ }^{2} \mathrm{e}^{2 \mu T}\left[\mathrm{e}^{\sigma^{2} T}-1\right]
$$

A gyakorisági függvény a szimuláció alapján a 7 . ábrán látható lett.

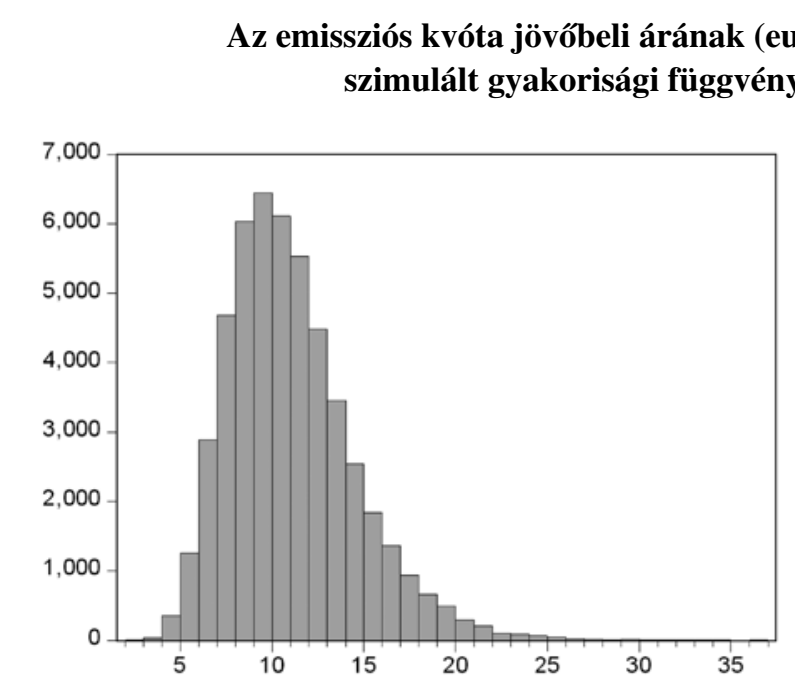

A szimulált eloszlás tipikus, balra ferde lognormál eloszlás, a magasabb árfolyamok esélye nagyobb, min normális eloszlás esetében. Az árfolyam kapott várhat értéke $(11,034)$ közel van az elméleti várható értékhez $(11,018)$, a szimulált szórás $(3,464)$ szintén jól kôzelíti
Nettó kvótapozíció euróban számolt értékéne szimulált sứrúségfüggvénye különböző birtoko kvótamennyiségek mellett

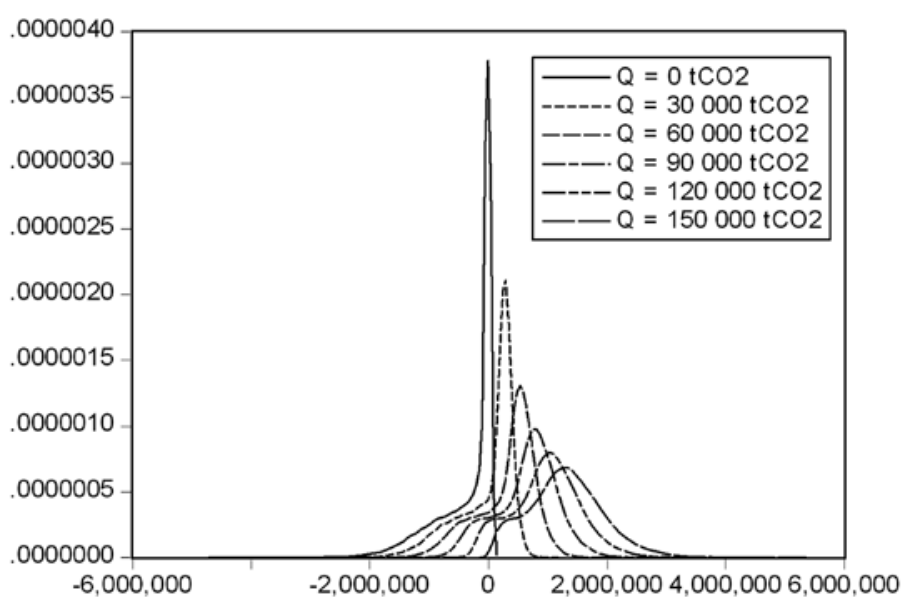

az elméleti szórást $(3,469)$. A továbbiakban nézzük meg, hogyan alakul a két kockázati faktor (kibocsátásés kvótaár bizonytalanság) együttes hatása.

A nettó kvótapozíció értékének meghatározása A nettó pozíció pénzben kifejezett értéke $\left(\mathrm{V}_{\mathrm{NP}}\right)$ meg-
mutatja, hogy adott idópontban a vállalatnak mennyibe kerïl lefedeznie kibocsétáśt (ha az érték negatív), ilpozitív). Értéke számítható a nettó pozíciómennyiség

7. ábra (NP) és a kvótaár $\left(\mathrm{S}_{\mathrm{EUA}}\right)$ szorzataként. Tegyük fel, hogy a vállalat $\mathrm{Q}$ mennyiségú kvótával rendelkezik. Az elszámolásra kötelezett vállala T idópontbeli nettó kvótapozíciójának értékét $\left(\mathrm{V}_{\mathrm{NP}}[\mathrm{T}]\right)$ megkaphatjuk a következó képlet szerint:

$$
V_{N P}(T)=N P(T) \cdot S_{E U A}(T)=
$$

$(Q-E m[T]) \cdot S_{E U A}(T)$

A képletben mind a $\mathrm{T}$ idópontbeli kvótaár, mind a vállalati kibocsátás valószínúségi változó, a szorzat a szimuláció segítségével számítható. Hat különböző kvótamennyiség $(\mathrm{Q})$ mellett a nettó pozíció értékének sưrüségfüggvénye a

Amint látható, kibocsátási egységek nélkül a nettớ pozíció értéke nulla vagy negatív (zérustól különbözố kibocsátás esetén a vállalatnak $\mathrm{T}$ időpont múlva biztosan fizetnie kell a pozícioja fedezéséert). A vásárol

\section{VEZETÉSTUDOMÁNY}


kvóta (Q) emelkedésével a nettó pozíció súrússégfüggvénye jobbra tolódik (a kvótafelesleget jelentố poz nettó pozícióértékek esélye megnő) és „ellapul ".

A különböző kvótamennyiség (Q) mellett levezethetố a nettó kvótapozíció várható értéke $\left(\mathrm{E}\left(\mathrm{V}_{\mathrm{NP}}[\mathrm{T}, \mathrm{Q}]\right)\right.$

$E\left(V_{N P}(T, Q)\right)=E\left[(Q-E m(T)) \cdot S_{E U A}(T)\right]=$

$E\left[Q \cdot S_{E U A}(T)\right]-E\left[E m(T) \cdot S_{E U A}(T)\right]$

$Q \cdot S_{E U A}(0) \cdot e^{\mu_{E U A} T}-c \cdot E\left(\Omega(T) \cdot S_{E U A}(T)\right)$

Amint látható kiemelhetố a vásárolt kvótamennyiségtốl (Q) függő tag, és a várható érték jelen (E(..)) belül csak a két sztochasztikus tag $\left(\Omega, \mathrm{S}_{\mathrm{EUA}}(\mathrm{T})\right)$ szorzata macsak a két sztochaszikus tag $\left(\Omega, \mathrm{S}_{\mathrm{EUA}}(\mathrm{T})\right.$ ) szorzata mali árfolyam $\left(\mathrm{S}_{\mathrm{EUA}}(\mathrm{T})\right)$ függenek egymástól, a szorzatuk várható értékét szimulációval célszerú becsülni (függetvárható értékét szimulációval célszerú becsülni (függetértékek szorzatával). A képlet alapján az is látható, hogy a nettó kvótapozíció várható értéke a rendelkezésre állo kvótamennyiség $(\mathrm{Q})$ lineáris függvénye, amelynek meredeksége az árfolyam várható értéke, a tengelymetszete az emisszió lefedésére szükséges T idốpontbeli pénzmennyiség ellentettje. A nettó kvótapozíció szimulát várható értékeit a 7. táblázat tartalmazza.

Nettó kvótapozíció várható értéke különbözó birtoko kvótamennyiségek mellet

\begin{tabular}{|c|c|c|c|c|}
\hline & \multirow{2}{*}{$\begin{array}{l}\text { sett VaR-értéket. A kockáztatott } \\
\text { érték számítást } 95 \\
\text { százalékos }\end{array}$} \\
\hline$\underset{t \mathrm{CO} 2}{Q}$ & $\begin{array}{c}\mathrm{E}\left(\mathrm{V}_{\mathrm{NP}}(\mathrm{T})\right) \\
E U R\end{array}$ & $\begin{array}{l}\mathrm{Q} \times \mathrm{E}\left(\mathrm{S}_{\mathrm{EUA}}(\mathrm{T})\right) \\
E U R\end{array}$ & $\begin{array}{c}\mathrm{E}\left(\mathrm{V}_{\mathrm{NP}}(\mathrm{T})\right)-\mathrm{Q} \times \mathrm{E}\left(\mathrm{S}_{\mathrm{EUA} A}(\mathrm{~T})\right) \\
E U R\end{array}$ & \\
\hline & -351347 & Wor & -351347 & konfidenciaszint (k) mellett elvé- \\
\hline 30000 & & 331006 & & \\
\hline & & & & \\
\hline & & & & gekhez tartozó kockáztatotl \\
\hline 120000 & 972677 & 1324024 & -351347 & ket a 10. ábra szemlélteti. \\
\hline 150000 & 303683 & 1655030 & -351347| & \\
\hline
\end{tabular}

A szimulált nettó pozico

Amint látható, a nettó pozíció várható értékéból levonva a kvótamennyiség (Q) és a kvótaár várható értékének szorzatát megkapjuk a kibocsátás fedezéséhez szükséges várható költséget, amely a birtokolt kvótamennyiségtốl függetlenül -351 ezer euró.

Optimális birtokolt kvótamennyiség meghatározás

Az elôbbiek ismeretében feltehetô a kérdés, hogy mennyi kvótát érdemes a vállalatnak a jelen idôpontban vásárolnia a T idôpontbeli kockázatának minimalizálása érdekében. A kérdés eldöntésére először egy kockázati mérték fogalomra van szükségünk. Erre használjuk a kockázatkezelésben elterjedt kockáztatott érték (Value at Risk-VaR) fogalmat,

\section{a várható nettó pozíciórték euróban kifejezett különbségének} súrúiségfüggvénye különbözó birtokolt kvótamennyiség mellett

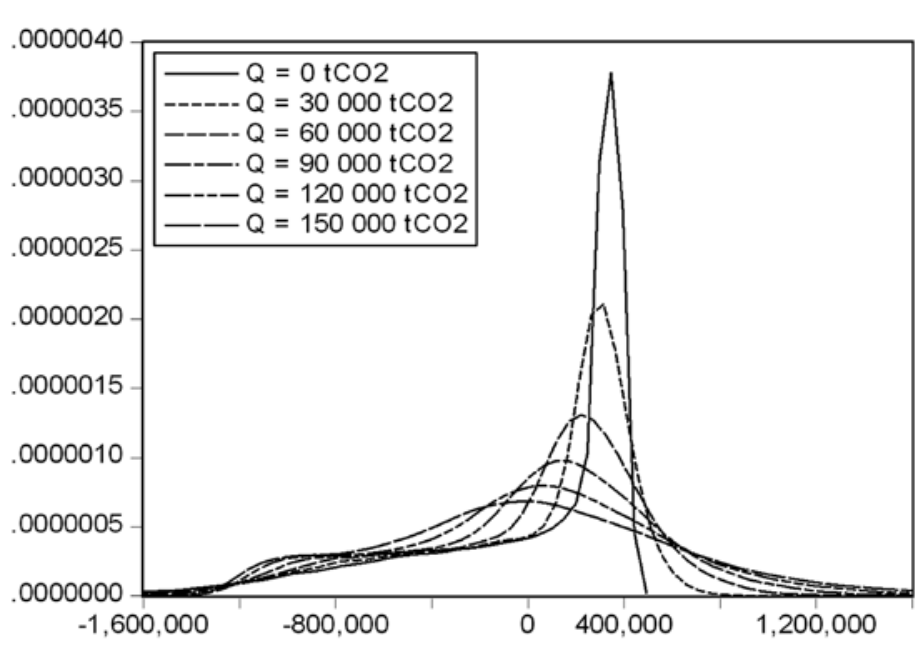

VEZETÉ STUDOMÁNY
$55 \%$-os konfidenciaszinthez tartoz kockáztatott érték (VaR) a birtokolt kvóta (Q) függvényében

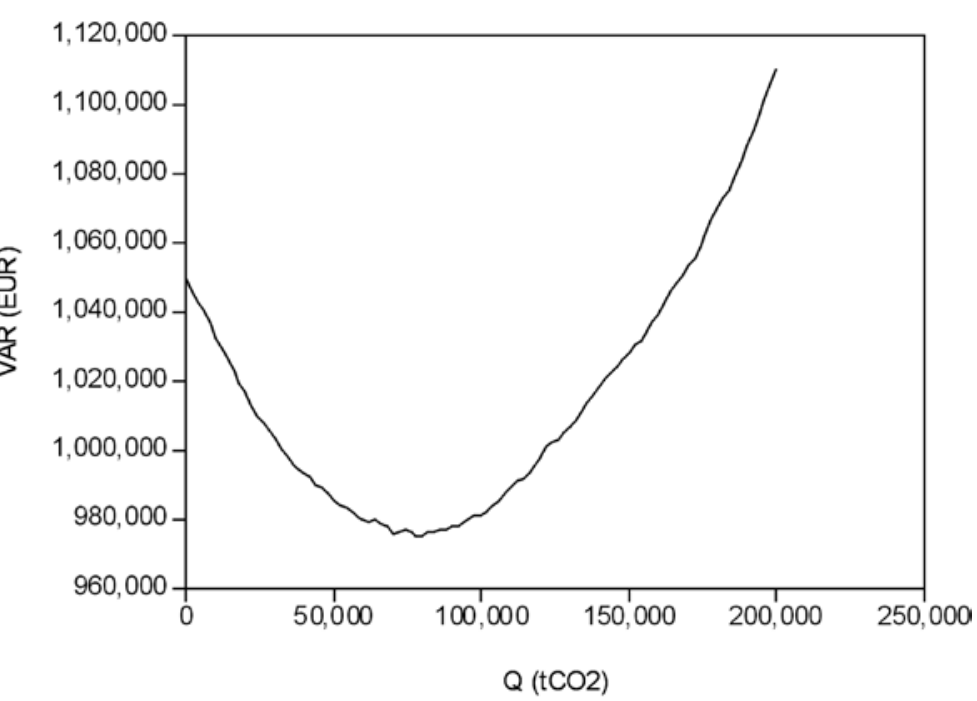
tatott erték felvesz egy minimumértéket. Ennek helye 76.640 tonnánál van (ez a 31.778 tonnás várható kibocsátás több mint kétszerese), értéke 975.500 euró. 95 százalék eséllyel tehát a teljes fedezés költsége nem fogja meghaladni a várható érték és 975.500 euró összegét. További kutatásra Tovabi ku vár éch hogyan alaku a VaR encicioja a szimulấciós paraméterek fuggvenyében, illetve hogyan alakulnak a szimulâlt súrúségfủggvények változó
volatilitást (például GARCH-modellt) feltételezve.

\section{Konklúzió}

Az EU ETS életbe lépésével az elszámolásra kötelezett vállalatok új típusú kockázati faktorokkal szembesültek, amelyek a saját kibocsátásuk alakulására és a kvótapiac áralakulására vonatkoznak. A kibocsátás és kvótaár sứrúségfüggvényének elơrejelzése kulcsfontosságú az optimális kockázatcsökkentési stratégia kialakításához. Ha a vállalat hosszú távú szerződésekkel nem rendelkezik, a termék, tüzelőanyag és az emissziós egység árainak alakulása határozza meg a vállalat ós egység árainak alakulása határozza meg a válláát Monte Carlo-szimulációval sikeresen becsülhetố a válMonte Carlo-szimulációval sikeresen becsülhetố a válszámítható nettó pozícióérték sưrúséśfüggvénye. A kaszámítható nettó pozícióerték sűrúségfüggvénye. A kapott eloszlásokból meghatározható az a kvótamennység, amelyet az adott konfidenciaszint mellett számított kockáztatott érték minimalizálása érdekében vásárolnia kell a vállalatnak. Alberola, E. - Chevallier, J. Cheaks in: European carbon prices 2005-2007. Energy Policy, 36 (2), p. 787-797.

Coase, R. H. (1960): The Problem of Social Cost. Journal of Law and Economics, 3 (1), p. 1-44. Convery, F. - De Perthuis C. - Ellerman, D. (2008). The European Carbon Market In Action. Lessons From The First Trading Period, Interim Report. Center for Energy and Environmenta

Convery, F. - Redmond, L. (2007): Market and Price Developments in the European Union Emissions Trading Scheme. Environment Economics and Policy, 2007 1(1), p. 88-111. Ellerman, A.D. - Parsons, J. (2006): Shortage, Inter-period Pricing, and Banking. Tendances Carbone, Volume

European Environment Agency (2002): EU reaches $\mathrm{CO} 2$ stabilisation target despite upturn in greenhouse gas emissions, http://www.eea.europa $\mathrm{eu} / \mathrm{pressroom} /$ newsreleases/greenhouse_gas_emission, Copenhagen, 29 April 2002, letöltve: 2010. 06.08

European Union Emissions Trading Scheme (EU ETS) data from CITL (2010); http://www.eea.europa.eu/data-andmaps/data/, letöltve: 2010.06.12

uropean Commission Environment Directorate-General (2009): EU Environment Policy Brief; Issue 27, May 2009, http://ec.europa.eu/environment/news/brief/2009_05 (20)

(2009): Aukciók az Európai Unió szén-dioxidkereskedelmi rendszer próbaidőszakában. Vezetéstudomány, XL. évfolyam, 6. szám

Hull, J. C. (1999): Opciók, határidős ügyletek és egyéb származtatott termékek. Panem-Prentice-Hall, Budapest erekes S. (2007): A környezetgazdaságtan alapjai. Aula Kiadó, Budapest

Aobor Á. (2000): A feltétel nélküli normalitás egyszerú alternatívái a kockáztatott érték számításában. Közgazdasági Szemle, XLVII. évfolyam, 2000. november, 878-898. o. Lesi M. - Pál G. (2004): Az üvegházhatású gázok kibocsátásának szabályozása, és a szabályozás hatása a villamosenergia-termeló vállalatokra Magyarországon. PhD Értekezés, Budapesti Közgazdaságtudományi és Államigazgatási Egyetem

agy T. (2010a): Effect of price uncertainty to power secto innovations. Springwind konferencia, Pécs

agy T. (2010b): Simulation of carbon-dioxide emission by option model; elókészületben, tervezett megjelenés: Society and Economy

Szaz J. (1999): Tózsdei opciók. Tanszék Kft. , Budapest

by (2005): Inventories of anthropogenic emission

by sources and removals by sinks of greenhouse

\section{VEZETÉSTUDOMÁNY}


gases; Sixth compilation and synthesis of initial national communications from Parties not included in Annex I to the Convention, Montreal, http://unfccc. int/documentation/documents/advanced_search/ items/3594.php?rec $=\mathrm{j} \&$ priref $=600003578 \#$ beg, letöltve: 2010.06 .11
UNFCCC (2010): Flexible Queries; http://unfccc.int/di/ FlexibleQueries/Event.do?event=go, letöltve: 2010. 06. 12 .

Cikk beérkezett: 2010. 6. hó

Lektori vélemény alapján véglegesítve: 2010. 8. hó

\section{Szerzőinknek}

A Vezetéstudomány a Budapesti Corvinus Egyetem Gazdálkodástudományi Karának havi, referált folyóirata. A lapban a vezetési és gazdálkodási tudományterületekhez kapcsolódó témakörök elméleti és gyakorlati kérdéseit elemző és vizsgáló írások jelennek meg. A szerkesztőség (robert.becsky@uni-corvinus.hu) elektronikus formában kéri az írásokat.

A cikkeket elektronikus levélben (MS Word fájl formátumban) lehet a szerkesztôséghez eljuttatni. A Vezetéstudományban megjelent cikkek magyar és angol nyelvú összefoglalói elérhetőek a http://www.vezetestudomany.hu és a http://vezetestudomany.hu címeken.

A lap tudományos folyóirat, ezért szövegközi forráshivatkozások és ezek jegyzéke nélküli írásokat nem jelentet meg. A Vezetéstudományban megjelentetni szándékozott kéziratok szerzőitől az alábbi követelmények figyelembevételét kérjük:

- A cikkek szokásos terjedelme a hivatkozásokkal, ábrákkal és táblázatokkal együtt 20-24 oldal, 1,5-es sortávolsággal (12-es betüméret, Times New Roman betútípus).

- A cikkek első oldalának alján tüntessék fel a szerző foglalkozását, munkahelyét és beosztását, elektronikus levelezési címét, a tanulmány elkészítésével kapcsolatos információkat és az esetleges köszönetnyilvánításokat.

- A kézirathoz csatolandó egy magyar nyelvú és lehetőség szerint egy angol nyelvú rövid összefoglaló (200 szót nem meghaladó terjedelemben), valamint a cikk fő témaköreit megnevező kulcsszavak jegyzéke.

- Kiemeléshez félkövér és dólt betû használható, aláhúzás nem. Jegyzeteket lehetóleg ne használjanak, amennyiben azok feltétlenül szükségesek, szövegvégi jegyzetként adják meg.

- A táblázatoknak és ábráknak legyen sorszáma és címe, valamint - átvett forrás esetén - pontos hivatkozása.

- Az ábrákat és a táblázatokat a kézirat végén, külön oldalakon, sorszámmal és címmel ellátva kérjük csatolni, helyüket a szövegben egyértelmúen jelölve (pl. „Kérem az 1. táblázatot kb. itt elhelyezni!").
- A szövegközi bibliográfiai hivatkozásokat zárójelben, a vezetéknév és az évszám feltüntetésével kérjük jelölni: pl. (Veress, 1999); szó szerinti, idézőjeles hivatkozás esetén kiegészítve az oldal(ak) számával (pl. Prahalad - Hamel, 1990: 85.).

- Amennyiben egy hivatkozott szerzőnek több bibliográfiai tétele van ugyanazon évben, ezeket 1999a, 1999b stb. módon kell megkülönböztetni.

- A felhasznált források cikk végén elhelyezett jegyzékét ábécérendben kérjük, a következő formában:

1. példa (könyv): Porter, M.E. (1980): Competitive Strategy; New York: The Free Press

2. példa (folyóiratcikk): Prahalad, C.K. - Hamel, G. (1990): The Core Competence of the Corporation; Harvard Business Review, május-június, 79-91. o.

A formai követelmények fentiekben érvényesített, ún. „Harvard” rendszeréról (más néven „szerzôlév” vagy „,név/dátum” hivatkozási módszerról) részletes tájékoztatást nyújtanak az alábbi WEB-címeken elérhető források.

Havi folyóirat lévén és a megjelenés átfutási idejének csökkentése érdekében a Vezetéstudomány kefelevonatot nem küld, elfogadás előtt azonban a szerzôknek egyeztetés céljából elküldi a cikk szerkesztett változatát.

2009. januártól a Vezetéstudományban publikált cikkek elérhetőek az ISI Eme „www.securities.com” internetcímen található strukturált on-line információs adatbázisban. 2009 júniusától a Vezetéstudományban közölt írások elérhetôek az EBSCO Academic Search Complete adatbázisában a http://web.ebscohost.com/ehost/search? vid $=20 \&$ hid $=102 \&$ sid $=747 a 764 f-362 f-4683-9255-4 e 54 f 5 b a 0 d f 7 \% 40$ sessionmgr 112 oldalon is.

Külön kívánságra 2004-ig visszamenóleg az összes korábbi kiadás publikációit elektronikus változatban is elküldjük.

Ha a szerző nem járul hozzá cikkének eseti kérésre, elektronikus úton való továbbadásához, kérjük, előre közölje ezt. 